Tanja Domej

\title{
Internationale Zwangsvollstreckung und Haftungsverwirklichung
}

\author{
am Beispiel der Forderungspfändung
}

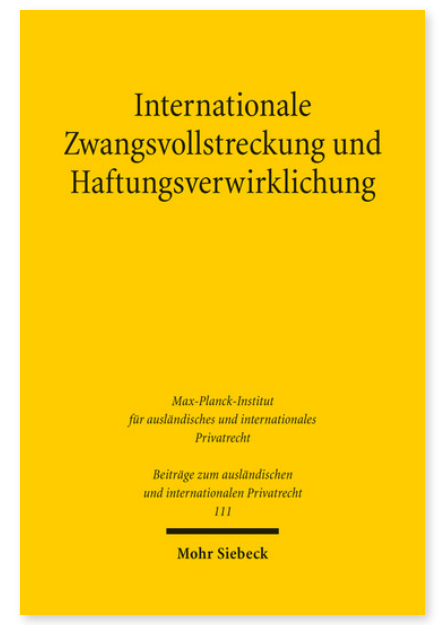

2016. XXVIII, 622 Seiten. BtrIPR 111

ISBN 978-3-16-152824-8

DOI 10.1628/978-3-16-152824-8

eBook PDF 94,00€

ISBN 978-3-16-152733-3

Leinen $94,00 €$
Das internationale Zwangsvollstreckungsrecht wird nach verbreiteter Auffassung durch das Territorialitätsprinzip beherrscht. Vollstreckungsakte, die ohne körperlichen Zugriff auskommen, können jedoch nicht eindeutig lokalisiert werden. Tanja Domej zeichnet aus vergleichender Perspektive die Kontroversen nach, die sich vor diesem Hintergrund um die Bedeutung des Territorialitätsprinzips für die grenzüberschreitende Forderungspfändung ranken. Sie zeigt, dass sich die relevanten Sachprobleme auf Basis dieses Prinzips nicht lösen lassen, aber auch eine schlichte Übernahme internationalzivilprozessrechtlicher Konzepte für das Erkenntnisverfahren den Besonderheiten des Zwangsvollstreckungsrechts nicht Rechnung trägt. Auf Basis einer Analyse der zuständigkeitsrechtlichen Interessen der Beteiligten entwickelt sie Perspektiven für eine interessengerechte Ausgestaltung der grenzüberschreitenden Zwangsvollstreckung in unkörperliches Vermögen.

Tanja Domej ist Professorin für Zivilverfahrensrecht, Privatrecht, internationales Privatrecht und Rechtsvergleichung an der Universität Zürich.

\section{Jetzt bestellen:}

https://mohrsiebeck.com/buch/internationale-zwangsvollstreckung-und-haftungsverwirklichung-9783161528248?no_cache=1 order@mohrsiebeck.com

Telefon: $+49(0) 7071-923-17$

Telefax: $+49(0) 7071-51104$ 